\title{
Evolution or Regression of Brazilian Education? Ten Topics of Education in Brazil from 1800-2000
}

\author{
Ferreira Ademir Antonio $^{1 *}$, Minotti Paulo Fernando ${ }^{2}$, Sousa, Demésio Carvalho de ${ }^{2}$ \\ ${ }^{I}$ University of São Paulo, Faculty of Economics and Management Accounting Department of Administration, \\ Senior Professor, Av. Luciano Gualberto 908 - University City 05508-010 Sao Paulo - SP - Brazil \\ ${ }^{2}$ University Paulista - UNIP, Master Program in Business Administration, Professors, R. Dr. Bacelar, 1212 - \\ Vila Clementino, 04026-002 Sao Paulo - SP - Brazil
}

\begin{abstract}
*Corresponding Author: Ferreira Ademir Antonio, 1University of São Paulo, Faculty of Economics and Management Accounting Department of Administration, Senior Professor, Av. Luciano Gualberto 908 University City 05508-010 Sao Paulo - SP - Brazil
\end{abstract}

\begin{abstract}
Going for research on the evolution of Brazilian education is not a simple task. A qualitative, descriptive and bibliographic study was initiated by presenting the method of choosing data collection (books, articles and magazines with a wide and rich variety of records on the subject). Highlighting aspects of epistemology, concepts, origin, global and regional evolution of education in Brazil, motivated this study. To reflect on these motivations, we highlight the works of many educations authors. fourteen references, with points of view that wanted to support the research. The main objective was to present a timeline with ten topics (facts) that directly influenced the foundations of Brazilian education in the period 1800-2000, to contribute to the academic knowledge of researchers in the area, as well as to society.
\end{abstract}

Keywords: Epistemology of education, evolution Brazilian education, governmental legislation.

\section{INTRODUCTION}

Social changes, motivated by the environmental and economic dimensions of the last centenary, have impacted educational curricula and teaching strategies in Brazil and around the world. From the technological transformations and the information age, society has changed to a new reality with new mechanisms that innovate the teaching-learning process, the classroom, the preparation of teachers, as well as the student demand.

It is not a simple task to look into the evolution of education as well as the influences on the basis of education in Brazil. It admits analysis, choices, authorial options, as well as the need to elucidate them to achieve the research objective.

This study is justified by Aranha (1996) "Only in the 21st century did historians begin to be interested in a systematic and exclusive history of education [...]. Even today there are huge gaps to be filled, "Rancière (2010) states" there will never be a definitive work", or even according to Vidal and Filho (2003) who stated that only" from the 1970s, as the emergence of the Post Programs - Graduation in Education in the country [...] has substantially increased the production of works in History of Education in Brazil ", that is, the stimulus to study becomes another humble attempt to add knowledge to the academy, as well as to society. by presenting a new historical point of view of education in our country. Finally, we highlight Engels (1983 apud FRIGOTTO, 2011, p.239) who stated: "every story needs to be re-studied $[\ldots]$ ".

This research sought to fill, even partially, gaps in the evolution of education in Brazil, and the general objective of the study was to present a timeline with 10 (ten) facts that directly influenced the basis of Brazilian education in the period between 1800-2000. For, as stated by Gadotti (2001, p.16) "the study of educational theory invites us to individual and collective action. We realize, therefore, that no issue should be trivialized [...]".

In order to achieve the general objective, three specific objectives were highlighted: a) to collect the records about the origin of education in society; b) understand the influences in the Brazilian 
educational system; c) highlight ten relevant facts of the Brazilian educational evolution in a timeline, with the justifications about each of the events.

Several authors have left contributions on the subject, but have not yet presented a timeline on education. The history of education unfolds in time and is part of the general history (ARANHA, 1996, p.19).

Education has its beginning with the appearance of man in the world, even primitively, but unanimously, in the civilizations of Egypt. In Western river or water communities (Egyptians, Sumerians, and Semites) as well as eastern (Chinese, Indian, and Indonesian) communities, learning was passed on among individuals as a means of survival, where children learned by imitating adult gestures as tradition and treatment were egalitarian, and education was essentially language-related (MANACORDA, 2001; SPIDER, 1996; CAMBI, 1999).

Writing has its origins since 3,500 BC, through Egyptian hieroglyphics, a term meaning sacred writing. In Mesopotamia the writings had cuneiform characteristics, that is, in the form of wedges. In China the feature has always been ideographic, complicated and representing ideas.

Basically a monopolization of writing began with the scribes in Egypt, wizards in Babylon, Brahmins in India until the arrival of the Phoenicians, around $1500 \mathrm{bC}$, when the alphabet, made up of signs representing sounds and assembled, spread. allow different combinations and facilitate the learning of writing (Aranha, 1996) and that was determinant for the development of development of education.

What can be seen in the totality of ancient artifacts that refers to education is that there was no specific reference to either school or professional learning, just a process of inculturation, exclusive to those who held power at the time, with elements of instruction formal and instrumental approach to the introduction of behavior and morals to the power management life (MANACORDA, 2001).

The teaching of Prince Hergedef, son of the king, to the very son he educates begins [...] following the usual ethical-behavioral advice: "Amend yourself before your eyes. Take care that others will not correct you. .. Create a home: marry a strong woman, a male child will be born to you. Build a house for your son ... Make your illustrious home in the necropolis. Seek to acquire ownership of flooded fields ... "(Br. 28). More than the inner conscience, morality seems to be directed to interpersonal relations [...] the universality of moral teaching seems to suffer social conditioning, since it is directed to a particular caste of individuals (MANACORDA, 2001, p.13-14 ).

With the ease of historical records through the Phoenician alphabet, the monopoly over writing diminishes and loses its sacred aspect and around 800 BC the Greeks assimilate the alphabet (Aranha, 1996, p.33).

Epistemologically the existence of education and the teaching-learning process can be considered from ancient Greece, from which the state appears as the center of power and the political aspect arises: democracy. The Greek provinces were autonomous and there was no monarchy installed, since individuals already exercised citizenship to vote and decide the destiny of the nation with debates and reflections so that the individual reached the paideia. Based on Homer's texts, the Greeks taught that the ideal was to be the best and to remain superior to others (GADOTTI, 2001, p.30).

In Greece, the ancient Mediterranean, the school institution developed in the cultural aspect. The Pedagogue - paidagogo - plays a fundamental role in the child's life, for it is controlled and stimulated by its teacher (CAMBI, 1999, p.49), as was done by Socrates (469-399 BC), who spread the irony ( in Greek "ask") and, consequently, maieutics (in Greek "childbirth") as didactic for learning at the time. The concept of maieutics is based on the art of giving birth to ideas in a dialectical way, that is, through dialogue. His disciple Plato (427-347 BC) founded the school called the Academy shortly after Socrates' death and even recorded his master's thoughts, such as the theory of paideia (school to form complete citizens for the future) and the work Dialogues. . Plato also had disciples, and one of them was Aristotle (384-322 BC) (CAMBI, 1999; GADOTTI, 2001).

With various criticisms of the maieutic method, Aristotle founded his own school called the Lyceum, in which he disseminated a new didactics for peripatetic-based learning, or learning by walking. Through the improved dialectic method, which analyzes the thesis and antithesis to arrive at the synthesis, in which the students listen and speak having an active participation in the construction of knowledge, being only assisted by the Professor (ARANHA, 1996; CAMBIS, 1999). 
After the Greek influence on education, the post-Socratic period of Alexander's empire had its crush on the Roman invasion. Through Cicero, a cultured individual who values the philosophical foundation of discourse, representative of the humanitas, proposes a rhetorical-literary period, in which Christianity causes a break in the goal of the Greek paideia and the Church creates the new Christian paideia, based on in biblical precepts (CAMBI, 1999; GADOTTI, 2001).

The Scholastic teaching method or the stifling of educational guidelines from the Clergy as a center of power was installed in Rome. Through this Roman method, from which the word school is derived, knowledge was disseminated to the owners of power and controlled by those linked to the Church, that is, power remained elitized. This teaching method deprived dialectics and instituted medieval learning, in which students only listened to the teacher and did not speak or generate any opinion, that is, the pedagogical strategy was based on long lectures. During this period, the term "teaching" or "teaching" emerged (GADOTTI, 2001; GARCIA, 2014).

Fava (2014) pointed out that the Roman Empire inserted a scenario of physical ruin and collapse of socio-educational principles, since the mastery of the arts of language, which were structured by the philosopher Boethius around the 6th century and systematized in trivium (liberal arts). grammar, rhetoric and dialectic) and the quadrivium (mathematical arts: arithmetic, geometry, astronomy and music), were selectively disseminated at the time, in order not to confront the evolution of Christianity.

Some Roman education theorists stood out as Cato (234-149 bC) who privileged the character formation; Marco Terencio Vararrão (116-27 BC) who focused on the Roman virtus; Marco Tulio Cicero (106-43 BC) who trained speakers with various qualities (humanitas based); Quintilian (35-96 AD) who focused on the discourse, as well as St. Anselm (1034-1109), Peter Abelard (1079-1142) and St. Thomas Aquinas (1225-1274) the greatest exponent of the scholastic call. The catechetical schools that centralized teaching by the Christian state made the school an ideological apparatus (GADOTTI, 2001; GARCIA, 2014).

While the western side of Europe changed according to the wishes of the clergy and their convictions, the eastern side of the world developed intellectually and culturally after Muhammad (570-632 AD) who founded Islam (islam = salvation) and wrote the Koran. There was the creation of libraries and the translation of classical Greek books into Arabic, so Greek philosophy served as the basis for Eastern knowledge. An example of this is the University of Karueein, Morocco (859 AD), considered the first university in the world by various historians, while in Europe there is the University of Bologna (Alma Mater Studiorum - Universitá di Bologna, 1.088) as the pioneer (GADOTTI, 2001; GARCIA, 2014).

A metaphysical clash between West and East occurred at the time of the Crusades, between 10961204, when Europeans were surprised by such eastern development. This era was of utmost importance for education and art, for not only did warfare occur, but also a cultural exchange between nations. The original books of Socrates, Plato and Aristotle were hidden with the Church in Europe, so the Europeans knew the Greek classics already translated into Arabic, and then were translated into Latin with this exchange of information during the period of struggle between the two. peoples. Not only in philosophy, but Europeans were amazed by the much more advanced medicine, mathematics and astronomy (GARCIA, 2014).

The cultural characteristics of passivity, submission, discipline and respect of students at school before their teachers, which lasted until the end of the twelfth century, gave way to a renewal in school design, with the advent of feudalism. The school starts to discuss and act outside the ecclesiastical walls of the cathedrals and monasteries, and the masters who did not show wisdom in the debates, lost their status and, consequently, removed their students due to the lack of encouragement to study (FAVA, 2014).

This confrontation of cultures, knowledge and experiences among peoples was the trigger for a new wave of education novelties, the so-called Renaissance movement (15th-16th centuries), Mercantilism with the arrival of Europeans in India and the Americas. The resumption of Greek thought, its values, around Plato's academy and Aristotle's Lyceum which confronted medieval scholasticism. Still in the sixteenth century, with full scholastic influence, Jesuit teaching emerged with the Ratio Studiorium, the first formalized pedagogical method. How to teach. With content fragmented by chairs or 
disciplines in a Pedagogical Course Project, Ignatius de Loyola (1491-1556) founded Jesuit education that influenced social and political life, with more scientific and moral than humanist education, pioneered the creation of a curricular learning matrix at the time, when it demonstrated an evolution of themes in degrees or levels of difficulty (Aranha, 2006; Gadotti, 2001).

In the seventeenth century, positivist naturalism emerged. The Discourse of the Method, by René Descartes (1596-1650), emphasized the Cartesian paradigm (concrete, innate), the evolution from the simple to the complex with a basic cycle of teaching from simple to the most complex subjects, as well as, the subjects should be. passed with logical chaining (causality). The author also presented the principles: of doubt, decomposition, synthesis and verification (ARANHA, 2006; GARCIA, 2014).

Aranha (2006, p.114) underscores the criticism of this cast method, which began to appear with John Amos Comenius (1592-1670), and the publication of Didactica Magna in 1638, which was based on the diminution of teachers' classes so students learn more.

In the mid-seventeenth century, a Protestant Reformation Lutheran monk named John Amos Comenius published DidáticaMagna, whose subtitle was revolutionary: the universal art of teaching everything to everyone, totally. The main focus was on teaching Latin reading and writing, so that the population had direct access to the scriptures, without the intermediation of the Catholic Church, but with some issues that are still used in our teaching-learning process (MINOTTI , 2011, p.31).

Another author who stood out at the time was John Locke (1632-1704), who criticized Descartes, defended empiricism (experience) and practice would lead the individual to intellectual growth and development. According to the author "men are good or bad, useful or useless, thanks to their education", or that is, education would model man to integrate body, moral and intellectual education. Locke as a representative of the bourgeoisie still emphasized the study of accounting, bookkeeping, geography, geometry and natural sciences for a broad preparation of practical life (Aranha, 2006; Garcia, 2014).

[...] the newly conceived is completely "raw" and without any cognitive disposition, because he will only possess it with the pressure that the medium will exert on him, that is, the subject is totally influenced and stimulated by the environment. . Sensitive experience is what marks this philosophy, because the word empiricism comes from the Greek empyria, which means experience (MINOTTI, 2011, p.33).

There are many changes, discussions and attempts to remove the "claws" of the Church that supplanted the wills of the thinkers of the time, and thus emerges the Enlightenment (eighteenth century), a movement that "frees" man from the threats of clergy and divine punishment. . Immanuel Kant (1724-1804) in his work "Critique of Pure Reason" in 1781, of which he defended independent thinking, daring to know was the author's principle. This period was marked by revolutions such as English (1688), United States (1776), French (1789) and some unsuccessful attempts here in Brazil (ARANHA, 2006, p.115).

However, Brazilian authors such as Paulo Freire (1921-1997) and Rubem Alves (1933-2014) are educators who based their theories on the Enlightenment bases, and will be explored in sequence (GARCIA, 2014).

Rousseau (1712-1778) goes beyond Kant's work in his work "Emile" by pioneering the concept of personality construction by the individual himself through his interaction with others in the pursuit of independence for natural interests rather than outward rules. imposed. During this period the first encyclopedia in France (1751) with D'Alembert (1717-1783) and Diderot (1713-1784) and the summary of content and knowledge on various themes were launched, in order to reinforce the idea that the individual is The French Revolution (1789-1799), with the premises "liberé, égalité, fraternité or la mort" is the concrete fact of the political expression of the need for liberation of European society at the time, formalized in the Declaration of Human and Citizen's Rights, which had a direct impact on the development of education (GARCIA, 2014; MANACORDA, 2001).

The nineteenth and twentieth centuries are marked by new historical changes as well as in the educational field. Andrew Bell (1753-1832) and Joseph Lancaster (1778-1838) create the more controlled teaching of mutual teaching with monitors to assist in teaching colleagues (GARCIA, 2014). 
Between Classical Antiquity (period extending from the seventh century BC to the fall of the Roman Empire in the fifth century AD) and the Renaissance (late thirteenth century until the mid-eighteenth century) there would have been a period of European history in which little was contributed. the development of humanity. It is the Middle Ages, called by many scholars as the Dark Ages or Dark Ages, a time of stultification, ignorance, bestiality, widespread underdevelopment, superstitions, beliefs, fanaticism, stagnation, cruelty (FAVA, 2014, p.01).

Shortly thereafter, John Dewey (1859-1952) sought to implement a new social pedagogical methodology based on the progress of the individual in a fair way, that is, he placed education as responsible for expanding the skills and experiences of students involving art, history and science. A Brazilian was a disciple of Dewey, and left the country to study the author's ideas in the United States to follow his theory, his name was Anísio Teixeira (1900-1971) a prominent educator in Brazil, which will be explored next when we quote the "Manifesto of Pioneers of New Education" (PILETTI; PILETTI, 2000; GARCIA, 2014).

After Dewey's theory became known, other thinkers devised innovations in the pedagogical method with in principle the student with the learning center rather than the teacher as in the scholastic method. Some of them are Steiner (1861-1925), Vygotsky (1896-1934) and Jean Piaget (1896-1980) who together with other authors will start the New School movement with one common point: the student as an active agent (constructivist) ) in the teaching-learning process.

Piletti and Piletti (2000) also highlighted the scientific pedagogical practice, which drew attention in the late nineteenth century and was implemented by the doctor and teacher Maria Montessori. With this theory the author defended the child's self-education in an obstacle-free environment, but enriched with objects (boxes of various sizes, cubes, pieces to be fitted, rough and smooth surfaces, bells with various sounds, etc.) suitable for sharpening the senses, the judgment and the reasoning.

Steiner (1861-1925) emphasized in his works the freedom and independence of the individual in the maximum intensification of the act of thinking, as well as of its functional application. It was normal to observe the object first and then elaborate a thought about it (BACH JUNIOR, 2012).

At the same time the German author Kerschensteiner (1854-1932) and the Soviet Makarenko (18881939) used the social pedagogy focused on educational work, which had utility-oriented characteristics (objectives) with a focus on the collective, the production of goods / services to society (PILETTI; PILETTI, 2000).

These authors and many others, after the end of World War I, influenced a movement to renew the global school structure, which in 1919 became known as the new school. Its premises, in short, are based on the following points: serve as a laboratory for an active pedagogy; open the mind to a general culture of individuals, but with specialization for professions; authority is replaced by the gradual emancipation and creation of leadership and social positions; develop creative skills, compare past and present to propose improvements; etc. (MANACORDA, 2001).

Vygotsky deepens his theory on human development and relationships with learning through the culturally organized and specifically human psychological processes called by the author the genetic approach. Another author, Piaget (1872-1978), presented an articulation of studies on the genetics of psychological development, in a structured and in-depth manner (OLIVEIRA, 2010).

Interaction with work, the sociocultural environment with the general evolution of humanity underlie the psychological development of each individual, since for Vygotsky it is not possible to emancipate himself in isolation. For Piageto, the psychological development of the operations goes through organic growth and maturation, the experience acquired in the action on objects, as well as in the interactions and social transmissions that the individual must pass through the life (MANACORDA, 2001).

From that moment on, there is the development of education in Brazil with the Proclamation of Independence, the "end" of the slave regime, the beginning of industrial development replacing the essentially agrarian economy and other events that influenced education in the country, which will be highlighted below.

\section{THEORETICAL FOUNDATION}

Academic articles in the field of education are represented by various theories of researchers that have contributed in some way to the teaching-learning process. This research will highlight the theories: 
dialectic, rationalist, genetic approach, constructivist and social constructivist, due to the relevance of the history of Brazilian education.

One notices, therefore, the human intellectual and vital need to know the key problems (when viewing the context; the global; the multidimensional; and the complex) of the world and to consider their complexity and the possibility of cognitive failure, in order to articulate and organize them to achieve thought reform. However, the education of the individual must adapt this knowledge to make it relevant to the world to which it is inserted (MORIN, 2000).

Knowing isolated data is insufficient for the individual, cognitive evolution occurs when establishing a contextualized and non-abstract knowledge. The recomposition of the whole, that is, the interrelation of a set of parts of a problem, is characterized as global. Multidimensionality (such as society, which is at the same time social, political, economic, market, technological, environmental, religious, etc.) must be recognized for knowledge to become relevant. And complexity, different elements that are inseparable constitutive of the whole, must also be considered the union between unity and multiplicity (BASTIEN, 1992; PASCAL, 1976 apud MORIN, 2000, p.36-38). In this chapter the influences of global education on the formation of the Brazilian educational bases, which came exclusively from Portugal, to demonstrate a multidimensional view of teaching in our country.

In Brazil, the Portuguese Jesuits dominated the colonization process in order to be producers and suppliers of genres for later trade in the European market. The direction of elite education disseminated by the Society of Jesus, which was based on the Ratio Studiorum, their focus was to disseminate education to the children of the colonists, to guide them in the formation of future priests and, therefore, was not aimed at popular education., even with the foundation of the "schools of reading and writing" (ARANHA, 2006). The courses involved Humanities (classical Portuguese authors), Philosophy and Theology (with scholastic foundations) (PILETTI; PILETTI, 2000).

The history of the structure and organization of education in Brazil reflects the socioeconomic conditions of the country, but reveals, above all, the political panorama of certain historical periods. [...] It is not possible to discuss education and teaching without reference to economic, political and social issues. Hence the choice of the 1930s, the beginning of the industrialization process in the country, to begin the study of the process of educational organization in Brazil. (LIBANEO; OLIVEIRA; TOSCHI, 2003, p.130-131).

For approximately three centuries Brazil has its well-defined social characteristics, from extremely submissive relations to the colony, the dependence on the economy was agrarian, as well as the slavelike mentality, not requiring skilled labor - characteristic of Brazil Empire - focused on the creation of Higher-level schools after the arrival of the royal family in the country (1808) due to the invasion of Napoleonic troops in Portugal (PILETTI; PILETTI, 2000; ARANHA, 2006).

The flight of the Portuguese royal family to Brazil came at a time of chaos installed in the fundamentally Jesuit Brazilian education (which served the interests of the "faith", with constant delinquency in the payments of teachers, who lacked the necessary preparation, were improvised and appointed by bishops to take up the royal classes), that is, this contrast of ideas led to the fall of the Christian principle of teaching and the beginning of an educational structure focused on the interests of the Court. Thus, the Jesuits were expelled from the country by the Marquis of Pombal, who implemented a study model with autonomous and isolated lessons of Latin, Greek and rhetoric (FAVA, 2014).

From 1810 to 1830 practically, an intense oppression of the market, with the Court installed in its colony, demands a new social structure as military hospital, military academy and polytechnic school are created in the country for the formation of doctors, nurses, chemists, locksmiths, geologists, economists, educators, etc., however, the slave regime and the agrarian economic model, which depended essentially on exports, maintained the aristocratic view of Brazilian education until the twentieth century (PILETTI; PILETTI, 2000; ARANHA, 2006).

The Joseph Lancaster Method (1778-1838), or method of mutual teaching, was instituted in the empire in an attempt to fill the teaching deficit in education. Based on a trained student who taught another group of ten students, being supervised by the Teacher, based on orality and repetition, so that the students were able to correct themselves, but was unsuccessful due to the lack of practical efficiency (FAVA, 2014). 
Following the promulgation of the 1824 Constitution, in the 1830s, a single general law focusing on elementary education was implemented in Brazil until 1946, stressing that "primary education would be free for all citizens". Prepared by Januário da Cunha Barbosa, in which he placed the State as responsible for the rational distribution of education throughout the empire, but still with an aristocratic and slave-based social base, the objective permeated only the "free men" and with an economic scenario. high public deficit, there were no investment conditions to restructure the state's academic bases in a popularized national education project (FAVA, 2014; RIBEIRO, 2000).

Ribeiro (2000) also points out that after the abdication of Dom Pedro I (1831) the Additional Act to the Constitution was decreed, which gave the Provincial Legislative Assemblies the power to legislate. This legislative change culminated in the creation of high schools and normal schools for teacher preparation in the 1940s, with the teaching of Latin, rhetoric, philosophy, geometry, French and commerce, ie, professionalizing and literature-based. European These changes were not enough to remedy teacher absenteeism and the lack of criteria in the assessment and approval of students, the focus of the complaints of the aristocratic elite of the time.

The decline of mining and the development of agriculture with the preponderance of sugarcane commodities and now coffee, which was beginning its profit cycle in Brazil, changed the Brazilian trade and economic structure in the $1850 \mathrm{~s}$, as well as the educational sphere, in which investments were made by the Court in the creation of institutions such as the General Inspectorate of Primary and Secondary Education of the Municipality of the Court (supervision of public and private education) in 1854, the reformulation of the Statutes of the Preparatory Schools, the Fine Arts and the Court's Trade Class in 1855. Even so, the poor preparation of students, the lack of attendance by teachers, the lack of scientific research, the elitism of teaching, and the lack of budget were still evident until 1870 (Ribeiro, 2000).

Fava (2014) comments that an effective educational model was not implemented in Brazil during this period, even with some reforms and the increase of higher schools, there was no significant evolution in teaching in our country due to the disconnect between school curricula and the characteristic focused solely on vocational training, ie, an efficient generic model was not identified in the academy.

Another interesting aspect highlighted by Aranha (2006) was the education of women in the colonial period, where they were isolated in their illiterate and reclusive houses (ashamed to relate to strangers) and only at the end of the eighteenth century a "High school and big house girls", elitized, only for the daughters of the planters of the time. In 1875 the normal school in São Paulo restructured and accepted women to add professional knowledge.

From 1900 until the 1930 Revolution, illiteracy reached alarming levels in a largely rural population, but with some improvements after World War I, where the demand for education rose as the country began to begin industrialization, urbanization and organization. of teaching. A new social profile emerged with the social, economic, and political events of the 1930s from industrial development and from an internal economic model that was agrarian to new industrialists. This favored the government of the time to offer a new and more structured popular education (LIBÂNEO; OLIVEIRA; TOSCHI, 2003; ARANHA, 2006).

With Getúlio Vargas in power, education passed began a process of more evident evolution. In 1930, the Ministry of Education and Public Health (MESP) was created, and in 1931 the Statute of the Brazilian Universities (which authorized the possibility of being public at the federal, state or municipal, and private) was approved, however, with the purpose of To bring the religious foundations closer to the government, the Christian leadership came to exert a strong influence on the pedagogical work of the institutions, in order to recrystallize Brazilian society. This change favored the creation of the first subordinate university, independently of the state, the ecclesiastical hierarchy with the Jesuits charged with the orientation and pedagogical administration of the institution, the Pontifical Catholic University - PUC, in Rio de Janeiro, in 1947 (FAVA, 2014).

Gadotti (2000) presented a research that encompasses traditional education (focusing on minority education, rooted in a slave-class society that survived until the Renaissance movement), internationalized education (based on the United Nations Educational, Scientific and Cultural Organization - UNESCO in the mid-twentieth century, aimed at eradicating global illiteracy), popular education (based on Freire's practices that also served as a mechanism for democratization) and new 
technologies (the diffusion of knowledge, mass communication, Internet learning and digital culture) that impacted this segment. However, a periodic line with ten main moments / authors since the origin of education was not highlighted.

From the postwar period until the military coup, Brazil consolidated increased employment in the public and private sector, the active participation of women in the market, mainly through teaching, and the training of specific teachers in the subjects of history, mathematics, geography, Portuguese, among others. Therefore, there was a process of integration of higher education with the creation of 22 federal universities, which generated a larger offer of places for teaching and expansion of enrollment. Another relevant aspect was the emergence of the National Students Union - UNE, which appeared with remarkable importance in the social context, as it organized the claims of students with the primary objective of obtaining social improvements (FAVA, 2014).

Fava (2014, p. 14) pointed out that:

After 14 years of processing in the National Congress, was promulgated in 1961, Law No. 4,024, the first National Education Guidelines and Bases Law (NEGBL-1) of Brazilian Education that, even allowing some flexibility, reinforced the traditional model of higher education institutions in force in the country, maintaining greater concern with teaching than with research and extension. The new law gave expressive authority to the Federal Council of Education, with the power to authorize and supervise new undergraduate courses, to deliberate on the minimum curriculum of each course, thus strengthening the centralization of the higher education system.

According to MEC (2017) in this decade, Brazilian education was still very centralized, and therefore inefficient in results. With the first NEGBL or NEGBL-1, the objective was also to give more autonomy to municipal and state agencies.

What seemed to be the redemption of education in Brazil was totally devastated by the military coup in 1964, which adopted the educational model as subversive and undemocratic, the military government imposes a patriotic ideology and focused again on the professionalization of the individual. Teacher arrests and layoffs, university raids, student clashes and many side effects on society have made the public education process troubled. In the midst of this hostile social environment, university reform takes place in 1968 and ensures autonomy for universities from a didactic, scientific, administrative and financial point of view (MEC, 2017). In 1971, the period considered to be the most forceful by the dictatorship (due to the truculence and oppression of those who were contrary to the aspirations of the government), the NEGB-2. From seven to fourteen years of age, from elementary school to high school, teaching became compulsory, with common curricula for first and second grades (MEC, 2017).

The 1980s are considered by many authors to be the "lost" decade, but the creation of the Ministry of Culture in 1985 and the promulgation of the 1988 Constitution, in which a new social planning forced the Government to provide childcare for children (up to three years old) in their budget (MEC, 2017). Another key factor for education was the entry into force of the NEGBL-3, as stated by Barretto (2015, p.681):

A decisive regulatory framework for teacher education in recent decades has been the NEGBL-3 act of 1996 (Brazil, 1996). Following the world trend, it determines that teachers of all educational levels are trained in higher education. Not without reason, the same law now considers distance education (DE) as a form of formal education at all levels of education, which favors the expansion of the required teacher education.

In the last two decades, globally and in Brazil, there were several processes of continuous changes in education, especially in higher education. This tendency of population accessibility to the third degree has advantages and disadvantages for the nation. The positive factors of educational expansion are directly based on the increase in the number of private and public higher education institutions which, from 1995-2010, grew by $262.52 \%$. Academic research focused on innovation, technology and science also accelerated, as a result, adding value to products and warm the internal and external capitalist market (MANCEBO; VALE; MARTINS, 2015). 
Also according to the research by Mancebo, Vale and Martins (2015), the negative factors of this acceleration of access to higher education stand out, as they are based on the privatization of Brazilian education, in a powerful and organized way through the large conglomerates (more $74 \%$ of enrollments are made in private institutions in recent decades) that have their representatives inserted mostly in the National Congress, ie, implement proposals of a commercial nature, profitable and profitable, unfortunately resulting in the loss of the central characteristic of education: the social dimension.

\section{RESEARCH METHODOLOGY}

A qualitative bibliographic study was chosen by presenting the method of choosing bibliographies and publication of articles in electronic media due to the variety of records on the subject. A bibliographic study for Marconi and Lakatos (2003, p.183) is based on sources Secondary:

[...] Bibliography already published in relation to the subject of study, from single publications, newsletters, newspapers, magazines, books, research, monographs, theses, cartographic material, etc., to oral media: radio, tape recordings. magnetic and audiovisual: films and television. Its purpose is to put the researcher in direct contact with everything that has been written, said or filmed on a given subject, including conferences followed by debates that have been transcribed in some form, whether published or recorded. [...] bibliographical research is not a mere repetition of what has already been said or written about a certain subject, but it allows the examination of a subject under a new approach or approach, reaching innovative conclusions.

Therefore, we initially searched for a hundred debibliographies, research in journals with titles containing the words "education in Brazil", "history of education in Brazil", "history of Brazilian education", "evolution of education" and / or "origin of education "in articles from the academic platforms of the Capes Foundation, Pontifical Catholic University, University of São Paulo, Paulista University UNIP (EBSCO Discovery Service), educational magazines and specific websites with videos on the subject. After this refinement, fifty titles were chosen that contained in their theoretical references citations on the historical evolution of education in Brazil and current affairs. Afterwards, the analysis was finalized and we decided on 20 bibliographies, articles, websites and a video that supported this study (references). The research aims to cover academic gaps on the subject, in view of the conceptual and direct focus in the search for ten relevant facts of the Brazilian history of education, and does not prevent the continuity and deepening of the study with the new technologies available for academic research.

\section{Results}

In order to achieve this general objective, three specific objectives were highlighted:

- collect records on the origin of education in society;

- understand the influences in the Brazilian educational system;

- highlight ten fundamental topics of the Brazilian educational evolution, from 1800-2000, in a timeline with the justifications about each of these facts.

To satisfy the first specific objective, the main studies were researched and presented, which approached several authors, which influenced the educational bases in the world, since its origin. Some names should be cited as the pillars of this goal: Homer (being the best and remaining superior to others), Socrates (amaieutics), Plato (the dialectic), Aristotle (the peripatetic), Cicero (humanitas), Quintilian (the discourse), Abelard and St. Thomas de Aquino (Christian teaching).

In order to contemplate the second specific objective, we investigated the main influences of our teaching, as well as briefly demonstrated the scenarios in which Brazil was inserted during its political, social and, consequently, educational development. Noteworthy in this regard were the Jesuits (theRatio Studiorum) and the Portuguese (the Royal Family) who formed the dorsal structure of the teaching model in the country.

Finally, and in an attempt to satisfy the ultimate specific objective and to contemplate the general objective of the research, Lancaster (the method of mutual teaching), the 1824 Constitution (primary education would be free for all citizens), industrialization in Brazil (the influence of modern administration, the end of World War I and the arrival of larger-scale machines for mass production in 
the country), the creation of MESP (Vargas government creates this ministry, approves the Statute of Brazilian Universities, in an attempt to recrystallize Brazilian society), after this, the LDBs of 1961 (autonomy of the municipal and state agencies), 1971 (the compulsory education from 7 to 14 years) and 1996 (the inclusion of early childhood education, adequate education professionals, the creation of FUNDEF, now FUNDEB), and 2000, in which there was a marked growth in private universities due to the large economic conglomerates remain strongly installed in the segment that should have as its objective a social and non-economic nature (which aims at profit).

Therefore, we highlight the ten (10) fundamental facts, focus of this research:

- O Radio Studiorum or Company of Jesus (Jesuit) - Ratio Studiorum (1800);

- A Corte Portuguesa or The Portuguese Court (1808);

- O Método Lancaster or The Lancaster Method (1810);

- A Constituição de 1824 or The Constitution (1824);

- O Brasil Indústria ou The Industrialization of Brazil (1900);

- O Ministério da Educação e Saúde Pública or The Ministry of Education and Public Health (MEPH) (1930);

- $\quad$ A $1^{a}$ Lei de Diretrizes e Bases da Educação (LDB-1) or The First National Education Guidelines and Bases Law (NEGBL-1) No. 4,024 (1961);

- $\quad A 2^{a}$ Lei de Diretrizes e Bases da Educação (LDB-2) or National Education Guidelines and Bases Law (NEGBL-2) No. 5672 (1971);

- $\quad$ A $3^{a}$ Lei de Diretrizes e Bases da Educação (LDB-3) or National Education Guidelines and Bases Law (NEGBL-3) No. 9,394 (1996);

- A Privatização do ensino or The Privatization of Education (2000).

With these facts and dates it was possible to format a timeline that allows the reader to view 10 (ten) facts that directly influenced our teaching bases, as follows:

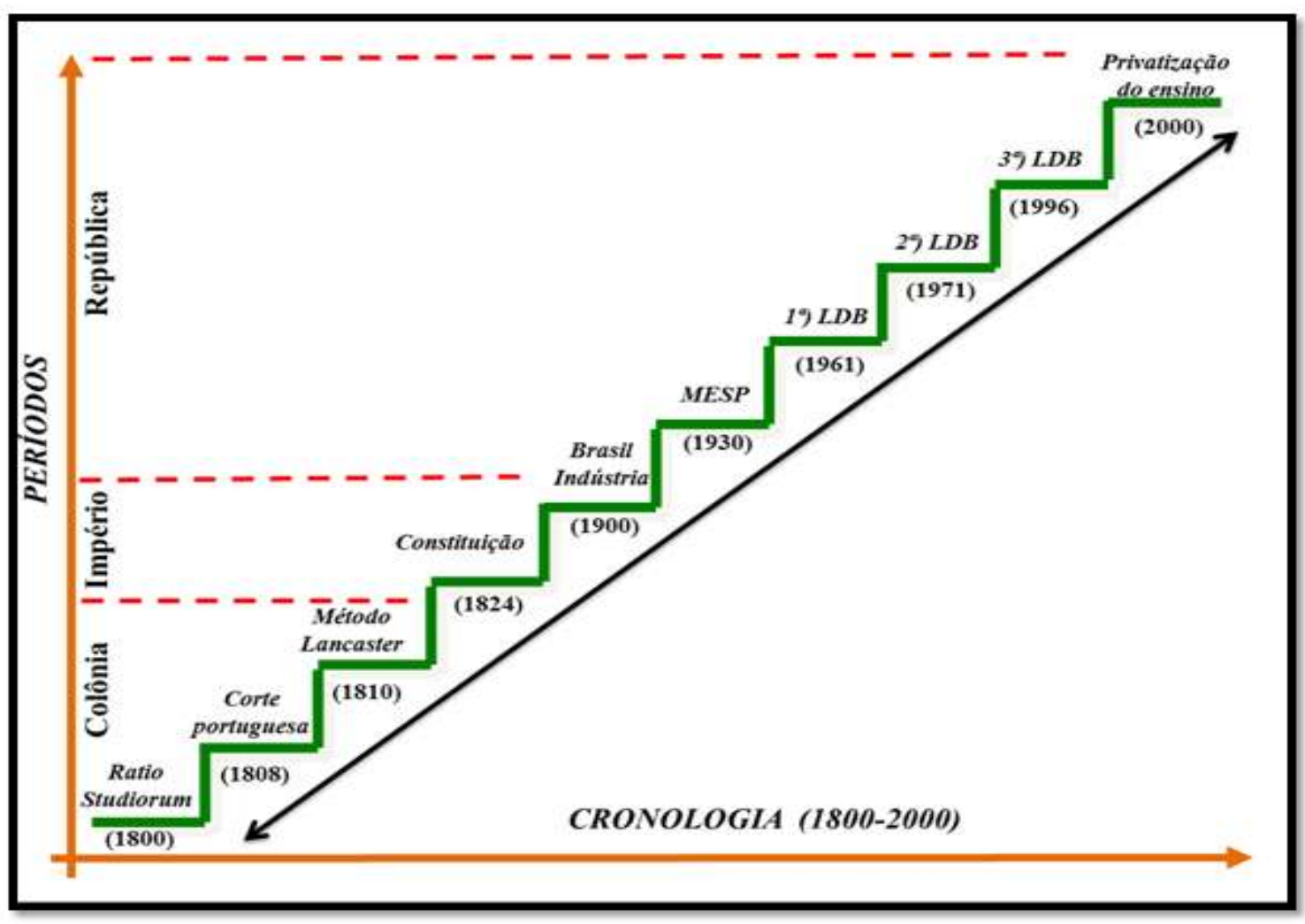

Figure1: The Timeline highlighting 10 (ten) facts that influenced directly the foundations of Brazilian education between 1800-2000. 
Source: Prepared by the researcher.

\section{CONCLUSION}

The objective of this study was based on presenting a timeline with ten facts that stood out in the bases of Brazilian education and their authors, in the period of 1800-2000 as a way of contributing to the academic knowledge of the researchers. as well as for society.

It was possible to identify in the research ten fundamental facts that directly influenced the foundations of education in Brazil, since it has not yet been implemented in our academic structure, a model considered ideal or appropriate that would allow us to improve our overall performance in this segment. This history can provide reflections on the critical success factors for our current situation, as well as support new research to deepen the theme.

A timeline of 10 (ten) facts that directly influenced the basis of education in Brazil and its current trends was presented. However, it is important to emphasize that this humble research is not definitive, but an opportunity for academic deepening for new students. future points of view and / or directions of studies focused on education, especially, focused on the theme of privatization of education in the country from the 21 st century.

\section{REFERENCES}

[1] ALVES, Luis Alberto Marques. History of Education: An Introduction. Faculty of Arts, University of Porto. Digital library. Porto, 2012.

[2] SPIDER, Maria Lúcia de Arruda. History of Education. 2nd ed. Sao Paulo: Modern, 1996.

[3] —. Philosophy of Education. 3rd ed. Sao Paulo: Modern, 2006.

[4] BACH JUNIOR, Jonas. Waldorf pedagogy as an education for freedom: reflections from a possible dialogue between Paulo Freire and Rudolf Steiner. Doctoral Thesis in Education. Federal University of Paraná. Curitiba, 2012. 409f.

[5] BARRETTO, Elba Siqueira de Sá. Teacher education policies for basic education in Brazil. Revista Brasileira de Educação- v.20, no62, jul./set.2015 and available at: <http://dx.doi.org/10.1590/S141324782015206207> access on 25 Jun. 2016

[6] BRAZIL - MINISTRY OF EDUCATION AND CULTURE (MEC) 2017. Available at: <http://portal.mec. gov.br/institucional/historia> Accessed on 25 Jan. 2017 (9:35 pm).

[7] CAMBI, Franco. History of pedagogy.Translated by Álvaro Lorencini. São Paulo: UNESP, 1999.

[8] FAVA, Rui. Education 3.0. 1st ed. Sao Paulo: Saraiva, 2014.

[9] FRIGOTTO, Gaudencio. The circuits of history and the balance of education in Brazil in the first decade of the 21st century. Brazilian Journal of Education - v.16, n.46, jan./abr. 2011.

[10] GADOTTI, Moacir. Current Perspectives of Education. Sao Paulo in Perspective. 14 (2), 2000.

[11] History of Pedagogical Ideas. 8th ed. Sao Paulo: Attica, 2001.

[12] GARCIA, Mauritius. A walk through the main moments of Western civilization that impacted the history of education. Posted 25 Oct. 2014 and available at: <https://www.youtube.com/ watch? V = bIJZAe XI4Fg> accessed 11 Jan. 2016.

[13] LIBANEOUS; Jose Carlos; OLIVEIRA, João Ferreira; TOSCHI, MirzaSeabra. School education: policies, structure and organization. Sao Paulo: Cortez, 2003.

[14] MANCEBO, Deise; VALE, Andréa A. do; MARTINS, Tânia B .; Higher education expansion policies in Brazil. Revista Brasileira de Educação- v.20, no60, jan./mar.2015 and available at: <http://dx.doi.org/10. 1590/S1413-24782015206003> access on 25 Jun. 2016.

[15] MINOTTI, Paulo F. The 21st Century Teacher: The Search for Excellence in Education through Flexibility. 1st ed. Sao Paulo. Authors Club. 2011.

[16] MORIN, Edgar. The seven knowledge necessary for the education of the future; translation by Catarina Eleonora F. da Silva and Jeanne Sawaya; technical review by Edgard de Assis Carvalho. 2. ed .; Sao Paulo: Cortez; Brasilia, DF: UNESCO, 2000.

[17] OLIVEIRA, Marta Koll. Vygotsky: learning and development: a sociohistorical process. 5th ed. Sao Paulo: Scipione, 2010.

[18] RANCIÈRE, Jacques. The emancipated bystander. 1st ed. Buenos Aires: Manatial, 2010. 
[19] SANTOS, Ademir V. Education and fascism in Brazil: the school formation of childhood and the Estado Novo (1937-1945) .Portuguese Journal of Education. 2012, 25 (1), pp.137-163. Federal University of Santa Catarina, 2012.

[20] VIDAL, Diana G .; FILHO, Luciano M. de F .. History of Education in Brazil: the historical constitution of the field (1880-1970). Brazilian Journal of History. São Paulo, v.23, no. 45, pp.37-70 - 2003.

Citation: Ferreira Ademir Antonio, et.al. "Evolution or Regression of Brazilian Education? Ten Topics of Education in Brazil from 1800-2000". International Journal of Humanities Social Sciences and Education (IJHSSE), vol. 6, no.11, 2019, pp. 57-68. doi: http://dx.doi.org/10.20431/2349-0381.0611009.

Copyright: (c) 2019 Authors. This is an open-access article distributed under the terms of the Creative Commons Attribution License, which permits unrestricted use, distribution, and reproduction in any medium, provided the original author and source are credited. 